\title{
'All in one stroke': Grimms' fairy tales and the TV-production of a new Germany
}

Article

Accepted Version

Wölfel, U. (2015) 'All in one stroke': Grimms' fairy tales and the TV-production of a new Germany. Oxford German Studies, 44 (3). pp. 271-288. ISSN 0078-7191 doi:

https://doi.org/10.1179/0078719115Z.00000000087 Available at https://centaur.reading.ac.uk/40874/

It is advisable to refer to the publisher's version if you intend to cite from the work. See Guidance on citing.

To link to this article DOI: http://dx.doi.org/10.1179/0078719115Z.00000000087

Publisher: Maney Publishing

All outputs in CentAUR are protected by Intellectual Property Rights law, including copyright law. Copyright and IPR is retained by the creators or other copyright holders. Terms and conditions for use of this material are defined in the End User Agreement.

\section{www.reading.ac.uk/centaur}

\section{CentAUR}

Central Archive at the University of Reading

Reading's research outputs online 


\section{'All in One Stroke': Grimms' Fairy Tales and the TV-Production of a New Germany}

Ute Wölfel, University of Reading

The article looks at the most recent TV adaptations of the Grimms' fairy tales by public broadcasting. Realised and marketed as a season which started in 2008, the thirty-four currently existing individual films constitute a significant national project that presents highly appealing notions of the German past to an audience divided over national conflict and demands of globalisation. With children and adolescents at the centre, the films offer the young as a generation of moral superiority that facilitates social harmony and moral consensus. This post-unification utopia is beautifully realised on screen, but rests on very conservative assumptions about gender, social driving forces and political order.

Keywords: childhood, post-unification, German, fairy tale, Grimm, public broadcasting, heritage

Jack Zipes ends his 2002 edition of The Brothers Grimm with a short discussion of the reception of the brothers' fairy tales after German unification and states:

The cultural production in the unified Germany during the last 12 years has reflected the crises of faith in the government and questioning of national identity. The issue of national identity is closely tied to shifts in the culture industry oriented more and more toward European interests. The role of the fairy tale in the cultural life of Germans today has become less clear. While the traditional tales of the Grimms continue to be reproduced and are well 
known, and while there are many fairy tale films, videos, advertisements, and children's books imported from other Western countries, there has not been an exceptionally new challenge to the Grimms' legacy that might reflect a different social and cultural attitude. While nationalism helped foster the Grimms' collecting and writing of tales that, they hoped, would bring about German unification, nationalism has become an 'ugly' term today, and writers and artists are reluctant to use the fairy tale or the Grimms' tales to display a new kind of nationalism. ${ }^{1}$

This apparent disregard for the 'national genre' soon changed when the antinationalist stance observed by Zipes was reversed. A prominent point of reversal was the 2006 Football World Cup in Germany during the preparations for which the government and industry worked to present a positive image of unified Germany to the world. Under the patronage of the then Federal President Horst Köhler and initiated by the government and the Bundesverband der Deutschen Industrie (BDI), a nation-branding campaign called Germany — Land of Ideas commenced in $2005 .^{2} \mathrm{~A}$ central part of the first stage of the campaign was the Walk of Ideas which between March and October 2006 presented sculptures of German 'inventions' in Berlin. Amongst the sculptures was a pile of books assembling what the makers of the

\footnotetext{
${ }^{1}$ Jack Zipes, The Brothers Grimm: From Enchanted Forests to the Modern World (New York, London: Palgrave Macmillan, 2002), p. 267.

${ }^{2}<$ http://www.land-der-ideen.de/initiative/willkommen-im-land-ideen> [accessed 8 January 2015].
} 
campaign regarded as the heaviest weights in German literature and philosophy; the Grimm brothers were of course among them. ${ }^{3}$

When in 2008 the Arbeitsgemeinschaft der öffentlich-rechtlichen Rundfunkstalten der Bundesrepublik Deutschland (ARD) broadcast its first season of TV-adaptations of the Grimms' tales, ${ }^{4}$ it seemed like a sequel to the branding exercise. Struggling with dramatically declining audience numbers and suffering from an image as broadcasting for pensioners, ${ }^{5}$ the ARD developed new formats to rejuvenate themselves and attract younger viewers. The adaptations form part of the strategy. The fairy tales' popularity and their status as cultural heritage as well as their national appeal promised wide interest. This potential turned into success due to the skill with which the ARD developed a framework for the tales and confirmed them as common German ground beyond social, political as well as generational divides, a strand of shared tradition and future identity in times of inner-German conflict as well as threats of globalisation. In the Presseheft published with the first series, ${ }^{6}$ the tales

\footnotetext{
${ }^{3}$ The sculpture had uncanny reverberations as it was placed on Unter den Linden near the old Royal Library at Bebel Platz were the Nazi book burning took place in 1933 and which since 1995 has housed the Book Burning Memorial.

${ }^{4}$ Not all adapted fairy tales are actually by the Grimm brothers; the ARD also included some of the most famous Hans Christian Anderson tales.

${ }^{5}$ See Volker Giersch, 'Nur noch ein seltenes Paar: Öffentlich-Rechtlicher Rundfunk und Jugend - Strategien gegen den Generationenabriss', in ARD Jahrbuch 2008, pp. 23-29, <http://www.ard.de/home/intern/gremien/aus-der-gvkarbeit/Fachartikel_und_Interviews/66906/index.html> [accessed 8 January 2015]. ${ }^{6}$ There was a Presseheft with each season. These can be requested from RBB Fernsehen <http://www.rbb-online.de/kontakt/index.html> [accessed 12 March 2015].
} 
were promoted by the ARD programming director as 'klassische Erzählungen, wie sie seit Jahrhunderten weitergegeben werden' and which the ARD adapted with the intention 'ein Kulturgut lebendig zu erhalten — dabei aber heutige Wertvorstellungen zu transportieren und alle modernen filmischen Mittel zu nutzen'. ${ }^{7}$ The overall aim of attracting children, the youngest target audience, and developing them into loyal longterm viewers generated ideas of childhood and Germanness that proved extremely appealing. Thus the battle for ratings produced a marketable image of the German Heimat that was accepted by post-unification audiences because it offered, I want to argue, an extremely positive and conciliatory image of the nation.

This article discusses which values these latest fairy tale adaptations so successfully present as relevant for post-unification Germany and which concept of childhood they reflect and help to shape. ${ }^{8}$ My overall hypothesis is that the ARD adaptations are formed by the desire for a national community based on social harmony and moral consensus. The child or adolescent is at the centre of this community and thus in the traditional role of the representative and facilitator of the

\footnotetext{
${ }^{7}$ Volker Herres, Vorwort, in Sechs auf einen Streich, ARD Presseheft 2008, p. 3. That the communication of moral concepts was core to the season can be seen from the Presseheft: This marketing material contains the category 'Und die Moral von der Geschichte ist' for each film giving one of the people involved in the respective productions the opportunity to summarise the tale's lesson. While the heading might indicate irony, the morals offered are far from ironic and reiterate homespun truths. ${ }^{8}$ Claudia Wegener, 'Der Kinderfilm: Themen und Tendenzen', in Kino in Bewegung: Perspektiven des deutschen Gegenwartsfilms, ed. by Thomas Schick and Tobias
} Ebbrecht (VS Wiesbaden, 2011), pp. 121-22. 
community's future. ${ }^{9}$ The focus on the young as the core of the nation uses them to negotiate common values and purposes with regard to the political order, the economic system and social driving forces.

\section{Reaching out to the Nation: Producing and Broadcasting the Grimms}

In 2005, three years before the ARD, the Zweites Deutsches Fernsehen (ZDF) had started an adaptation project which has so far resulted in one or two full-length fairy tale films of moderate success each Christmas. ${ }^{10}$ These films are close to the format of the internationally co-produced fairy tale adaptations from the 1980s and early 1990s commissioned and at times co-produced by the $\mathrm{ZDF},{ }^{11}$ which were individual, i.e.

\footnotetext{
${ }^{9}$ At first glance, the films present childhood differently from adolescence. While adolescence is translated throughout into coming-of-age stories in which social and emotional maturation are reached, childhood is depicted as a phase in which the minor needs the social stability and emotional security of the family or village. At second glance, however, the films do not differentiate significantly between childhood and adolescence in that both, the increasing maturity of the adolescent as
} well as the dependence of the child, confirm the same values and ideals.

${ }^{10}$ These were retrospectively branded Märchenperlen.

${ }^{11}$ In the 1980s and 90s, the ZDF together with other European TV stations, particularly the Austrian ORF but also the Italian Raiuno, and the Spanish TVE commissioned and/or co-produced a number of fairy tale films; the two main production companies were Omnia Film GmbH Munich and Slovenska Filmova Tvorba Bratislava. Due to their pan-European production status, these films do not focus on a national agenda and notably fuse different film traditions, with the Czechoslovakian tradition as the most dominant. Although some of the films already 
discrete films. In contrast to this, the successful ARD adaptations were produced and broadcast as seasons of several films each lasting 60 minutes, and marketed as a brand, Sechs auf einen Streich, from the beginning. Under the auspices of Rundfunk Berlin Brandenburg (RBB), the bulk production was split among the various broadcasting corporations of the ARD which contributed one or more of these films, ${ }^{12}$ each of which had a budget of $€ 1$ million and consequently high production values. The production of several famous fairy tale adaptations as part of a single marketing strategy guaranteed public attention and discussion. Strategically clever, the ARD broadcast the films on Das Erste over the Christmas period. The six films of the first season in 2008 were shown twice - three just before and three just after Christmas and all six in 2 blocs on Christmas Day from 2 to 5pm and on Boxing Day from 2.30 to $5.30 \mathrm{pm}$ respectively. ${ }^{13}$ The season thus occupied a significant portion of family prime-time TV. This strategy was rewarded with fantastic viewer ratings; the second season in 2009, which presented eight new films, reached 3.4 million viewers over

use national or even international stars as crowd-pullers these remain part of an international ensemble — Libuše Šafránková (Der Salzprinz 1982) who became famous as Aschenbrödel in the truly landmark adaptation Drei Haselnüsse für Aschenbrödel (1973), Maria Schell (König Drosselbart 1984), Giulietta Masina (Frau Holle 1985), Judy Winter (Dornröschen 1989), Iris Berben and Michael Degen (Froschkönig 1990), and Dietmar Schönherr and Gudrun Landgrebe (Schneewittchen 1992).

${ }^{12}$ In most cases, the respective corporations commissioned the films.

${ }^{13}$ Sechs auf einen Streich, ARD Presseheft 2008, p. 2. 
Christmas and a market share of $27 \% .{ }^{14}$ The ARD reflected on this success in its report for 2011/12:

Nach den großen Erfolgen der vergangenen Jahre setzt Das Erste im Rahmen einer nachhaltigen Eventprogrammierung wie angekündigt die Verfilmung bekannter und attraktiver Märchenstoffe fort. Im Weihnachtsprogramm 2011 sendete Das Erste erneut die Märchenfilm-Reihe Sechs auf einen Streich. [...] Die Zuschauerakzeptanz blieb mit einem Marktanteil zwischen 12,6 und 17,8

14 'Das Fernsehpublikum hat der ARD-Märchenreihe Sechs auf einen Streich zu Weihnachten zauberhafte Einschaltquoten beschert. Vier Neuverfilmungen und zwei Klassiker aus den Jahren 2008 und 2009 präsentierte Das Erste in seinem Feiertagsprogramm am Nachmittag. Den größten Zuschauerzuspruch erhielt in diesem Jahr das WDR-Märchen Des Kaisers neue Kleider mit Matthias Brandt u. a. am zweiten Weihnachtstag mit durchschnittlich 2,83 Millionen Zuschauern (Marktanteil von 16,0\%). Die Prinzessin auf der Erbse (RBB) mit Iris Berben u. a. erreichte 2,72 Millionen Zuschauer (15,3\% MA), dicht gefolgt von Der Meisterdieb (NDR) mit Max von Thun u. a. mit 2,61 Millionen Zuschauern und einem Marktanteil von 16,1\%. Das blaue Licht (HR) mit Veronika Ferres als Hexe schalteten am ersten Weihnachtstag im Durchschnitt 2,39 Millionen Zuschauer (15,4\% MA) ein. Auch die Wiederholung der beiden Märchenfilme aus den Vorjahren, Rapunzel (2,18 Mio., 15,2\% MA) und Tischlein deck dich (1,94 Mio., 12,6\% MA), erfreuten sich eines großen Zuschauerinteresses’ <http://www.presseportal.de/pm/6694/1740166/maerchenhafte-quoten-fuer-sechsauf-einen-streich> [accessed 8 January 2015]. 
Prozent 2011 erfreulich hoch. Im Durchschnitt erreichten die Märchenfilme im Weihnachtsprogramm 2,32 Millionen Zuschauer. ${ }^{15}$

The adaptations were indeed so successful that over Christmas 2014 the seventh season held TV-viewers spellbound, presenting another four to a current total of thirty-four films.

While strategic placing and status of season generated public attention and a broad audience, other aspects of the production proved equally ingenious. Looking at the cast of the first of the 2008-season's film, Tischlein deck dich (Ulrich König, WDR), one is struck by what one critic called a 'beachtliche Stardichte'. ${ }^{16}$ The hourlong production stars Winfried Glatzeder, Ursula Karusseit, Christine Neubauer, Michael Brandner, Wolfgang Winkler, Dietmar Bär, and Helmut Zierl, i.e. a total of seven actors from former East and West Germany well known to a post-unification audience from TV, cinema and stage. With very few exceptions the 'Stardichte' from both Germanys remained a feature of all the adaptations. Considering that a good number of these stars are closely associated with specific locations due to their longstanding parts in TV-series - particularly the successful Sunday prime-time crime series Tatort and Polizeiruf - , their appearance in the fairy tale films also represents the various regions of Germany. National stardom is here profitably exploited as

\footnotetext{
${ }^{15}$ Bericht der ARD über die Erfüllung ihres Auftrags, über die Qualität und Quantität ihrer Programme sowie über die geplanten Schwerpunkte, p. 69. <http://www.daserste.de/specials/ueber-uns/ard-leitlinien-2012-100.pdf> [accessed 8 January 2015].

${ }^{16}$ Peter Luley, 'Grimm für Anfänger', <http://www.spiegel.de/kultur/gesellschaft/maerchenfilme-in-der-ard-grimm-fueranfaenger-a-597543.html> [accessed 30 January 2014].
} 
crowd-puller and seems a guarantee of local representativeness within the national framework.

Representativeness is a key element also with regard to the films' locations. All of the films - even though some of them include studio-shot and/or computergenerated fantasy sites - were filmed on location and rely on Germany's historical landscapes. Each film merges various locations which, however, come from the same region and period and thus convey the impression of historical consistency as well as regional specificity. The latter is further underlined by the use not only of historical dress but also regional costume. Relying on numerous open-air museums, medieval castles and monasteries as well as $18^{\text {th }}$-century palaces, historical buildings and assets were used for indoor and outdoor shooting throughout. The adaptation of Die Prinzessin auf der Erbse (Bodo Fürneisen, RBB 2010) operates on the visual axis between a typical mid-18 ${ }^{\text {th }}$-century palace (Schloss Mosigkau) and the red brick Kloster Chorin giving a familiar picture of the historical landscape around Berlin. With its redbrick-timbered, reed-roofed houses, the flat pasture landscape, and farmhouse gardens, Der Meisterdieb (Christian Theede, NDR 2010) represents a typical northern German landscape whereas Schneewittchen (Thomas Freundner, MDR 2009) presents medieval castles from Saxony and the craggy romantic landscape of a typical low mountain range, the Harz.

The films' grounding in historical sights and the various landscapes of Germany intensifies the national agenda of the adaptations and works on the restoration of Heimat. This is particularly promoted by the visualisation of the natural landscape: whether craggy or gentle, flat or hilly, sea or brook, meadow or forest, seldom has German landscape been presented as so unspoilt, lush, and potent. The films' use of balanced and deep compositions and their reliance on colour grading 
which creates a palette of natural, warm and saturated colours opens up nature as 'the place where one feels at home with oneself' ${ }^{17}$

The concepts of the beauty of nature and of Heimat are closely related. They both invest an inanimate Other with shining subjective qualities that reflect themselves back as identity. [...] Heimat has absorbed the beauty of nature and given it a geographical grounding. ${ }^{18}$

The images draw on the archive of landscape painting from Romanticism to Realism, which contributes considerably to the films' high production value. It would not be wrong to call the ARD adaptations small-scale heritage films which apply Germany's natural and historical monuments to confirm a traditional and idealised vision of the national past. The mise-en-scene evokes various historical periods 'as a source of visual attraction' and applies what has been termed the 'museal gaze'. ${ }^{19}$ The fact that there are no specific historical events portrayed in any of the films may contest the link to heritage filmmaking; however, the remaining vagueness of the historical past helps to evoke pastness as a nostalgic concept offering its materials and textures as even more pleasurable. The moral lessons which this past seems to yield, claim validity by virtue of being untarnished by problematic, painful or shameful historical

${ }^{17}$ Peter Blickle, Heimat: A Critical Theory of the German Idea of Homeland (Rochester, NY: Camden House, 2002), p. 17.

${ }^{18}$ Ibid, pp.121-22.

${ }^{19}$ Lutz Koepnick, 'Reframing the Past: Heritage Cinema and Holocaust in the 1990s', New German Critique, 87 (2002), 47-82 (p. 50). 
events. Just as the many open-air museums used in the films, the films themselves 'transform the past into an object of consumption' ${ }^{20}$

All the films have children and/or adolescents as their protagonists and belong to the meta-genre of children's film, i.e. they tie in with media competence and narrative understanding of the age group 6 to 12 years. ${ }^{21}$ However, the intergenerational appeal of the tales ${ }^{22}$ as well as the broadcasting time of the seasons and the casting decisions indicate that other age groups are also targeted. It is not important for 6- to 12-year-olds whether an actor is famous and what for, but for parents and grandparents who are attracted by those they have known and liked all their lives. This suggests that the ARD adaptations belong to the family-entertainment segment of children's film, a classification also supported by other adult specific elements such as the use of comic figures that rely on word play, or the use of visual metaphors. ${ }^{23}$ Last but not least, family entertainment is determined by an emphasis on

${ }^{20}$ Ibid. That there is a business side to the heritage-approach can be seen from the fact that all the films' locations were listed first in the Pressehefte and are now on a tourism website <http://www.visitatio.de/Maerchendrehorte/ $>$ for attracted visitors [accessed 12 March 2015].

${ }^{21}$ Horst Schäfer and Claudia Wegener, 'Kindheit und Film', in Kindheit und Film: Geschichte, Themen und Perspektiven des Kinderfilms in Deutschland, ed. by Horst Schäfer and Claudia Wegener (Konstanz: UVK, 2009), pp. 9-21 (pp. 11-12). ${ }^{22}$ For the important role of adults' nostalgia in this context see Alexandra Loyd's article in this issue.

${ }^{23}$ Des Kaisers neue Kleider (Hannu Salonen, WDR 2010) for example develops an elaborate visual play on forms of vision and blindness, states of 'being seen' and 'not being seen'. 
family related topics, ${ }^{24}$ and the adaptations' focus on the community is a case in point. The concern for the community discussed through the children/adolescents allows all the films to broach issues of intergenerational interest such as relations between parents, children, grandparents, peers, poor and rich, ruler and ruled. As almost all the films follow the community approach and explore the conditions of communal cohesion, they contribute to a discussion of the 'community of values' on a national level and help a 'national identity to be constructed in the Berlin Republic that will be acceptable to citizens'. ${ }^{25}$

\section{Adapting a Communal Concept}

The first film of the first season, Tischlein deck dich, is an exemplary illustration of the community-based take. The Grimms' version tells the story of three sons who fall out with their father due to a mischievous goat; the three sons have to leave home and learn a trade while their father sees his mistake and chases the goat away; as the three sons are on their way back home again with fantastic presents from their respective masters, an innkeeper tries to steal these but is forced to return them when the third son sets his present in action, the 'cudgel in the sack'; the tale ends with the reconciliation of father and sons.

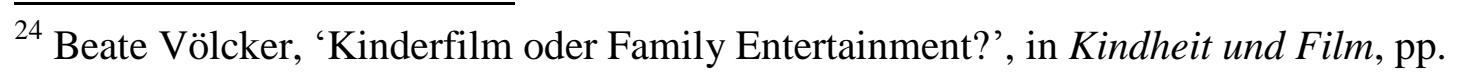
231-41 (p. 236).

${ }^{25}$ Elizabeth Boa, 'Telling It How It Wasn't', in German Memory Contests: The Quest for Identity in Literature, Film, and Discourse since 1990, ed. by Anne Fuchs, Mary Cosgrove, and Georg Grote (Rochester, NY: Camden House, 2006), pp. 67-86 (p. $67)$. 
In the ARD adaptation there are a number of changes which serve the individualisation of characters and at the same time their integration into a more complex social structure. The differences with the father are limited to the third and youngest son Max, who is treated by the members of his family as the least able; the conflict has thus shifted and the main story becomes Max's attempt to prove himself capable and grown-up to his father and older brothers. This focus singles out the youngest son for the audiences' attention and offers him as the emotional point of identification. This is further developed by a love interest of Max's, Lotte, which adds the topic of true love to the tale of growing-up and at the same time gives the rite of passage a female exponent. While these alterations allow the audience to relate emotionally to the individual, they also open up a more complex interplay between individual and community than does the Grimms' version. The events relating to Max and Lotte are developed as parallel-plots which look at the difficulties young people face when having to find their place in life, i.e. learning a trade, gaining recognition, and defending ideals and moral convictions. By looking closely at the individual's difficulties, both strands also reflect problems caused by the families which don't take the young generation seriously or their wishes into consideration due to financial hardship. The family tensions in their turn point to a communal imbalance as the richest farmer in the village proposes to buy Lotte for his dull son and thus save Lotte's widowed mother from poverty. These interrelated conflicts between individual, family, and village are solved in the end: on his return, Max has accomplished even more than his brothers by having not only learnt but innovated his trade, saved his brothers' rewards and married Lotte, all of which allows reconciliation within Max's family and the wider community: the rich farmer is humiliated, Max's father marries Lotte's mother, and even the mischievous goat is 
forgiven. The last shots of the film show the double wedding with the two families sitting around a big table, young children playing, and the farm animals enjoying their share of the feast. Children and parents, man and woman, man and animal are happily reunited on the basis of honest work, true love and forgiveness.

The utopian wish to reconcile the generations, the sexes, and the species is apparent in most of the adaptations and the success of such reconciliation is linked throughout to the bourgeois ethos - truth, integrity, and diligence - and the punishment of falsehood, greed and profit-seeking as the 'Moral von der Geschichte' from the producer of the film, Martin Hofmann, in the Presseheft may illustrate: 'Bleibe wahrhaftig und redlich, denn die Intrige schadet am Ende demjenigen, der sie anzettelt. $^{, 26}$

Within this framework, it is the role of the children and adolescents to expose the conflicts and set them in motion thus inducing change. The following discussion will scrutinise change as harmonisation and pay particular attention to the treatment of conflicts. Analysing three examples - Hänsel und Gretel (Uwe Janson, RBB and SR 2012), Rotkäppchen (Sybille Tafel, HR 2012) and Die Sterntaler (Maria von Heyland, SWR 2011) —, I will highlight key issues revisited throughout the seasons and therefore central to the TV screen foundation of the new German community: economic exploitation, gender roles, and political hierarchies.

\section{Hänsel und Gretel: Critique of Common Capitalism}

${ }^{26}$ Presseheft 2008, p. 5. 
The adaptation was commissioned by the RBB and Saarländischer Rundfunk (SR); it was directed by Uwe Janson ${ }^{27}$ and had its TV premiere as part of the fifth season on Boxing Day 2012 with 2.10 million viewers. The film is characteristic of the season as a whole in that it stars well-known actors from East and West such as Anja Kling, Devid Striesow and Johann von Bülow. The fact that it had an earlier screening in November 2012 at the Frankfurter Buchmesse as part of the $200^{\text {th }}$ anniversary of the first edition of the Kinder- und Hausmärchen in 1812, underlines the seasons' national aspirations.

In 2006 the ZDF had broadcast its own new adaptation of the tale which followed the Grimms' plot closely, visually stressing the horror-elements of the story. The ARD on the other hand used as its model a more conciliatory version, namely Engelbert Humperdink's opera of the same title from 1893. Humperdink's late romantic adaptation moderated the parents' part in the abandonment of the children and also mitigated the role of the witch; the children she catches are turned into gingerbread figures rather than cruelly murdered and they are restored through her death. Sticking to these family-friendly changes, the father of the ARD adaptation is a loving parent who deeply regrets agreeing with his new wife's plan to leave the children in the woods and, consequently, goes looking for them. This facilitates parallel plots which follow the father on the one hand and the children on the other resulting in a shift of focus from the children to the family; saving the children becomes a joint effort particularly as the father meets a wise woman who helps him in his search, which ends with the family reunion and, following the Humperdink story, the resurrection of the other victims.

\footnotetext{
${ }^{27}$ Janson also directed the most successful of the adaptations so far, Aschenputtel
} (WDR 2011). 
The main characters are individualised, and the children in particular receive psychological fine-tuning. Hänsel acts the 'big brother' who teases his 'little sister' showing off with his courage and reason while at the same time suffering from his mature understanding (of the parents' intentions) and the self-imposed task of protecting his sister. He is carrying a burden beyond his age. Gretel complements her brother in that she has not yet lost her 'innocence', i.e. she is naïve, spontaneous and acts intuitively. Unlike Hänsel whose maturity and reason make him lonely, Gretel is still housed in the 'animated' world of childhood as symbolised by her doll and her special relation to a magical chair in the witch's house.

The relationship between brother and sister is credible and offers a convincing point of identification for child audiences who get the opportunity to see how children 'like themselves' overcome a most dreadful threat by relying on each other. While this strengthens the position of the child, the father who admits and regrets his mistake in word and deed further supports the empowerment of the young. Indeed, the children appear as figures of authority while the father goes on an actual and symbolic journey through the woods in order to acknowledge his failure and redeem his guilt. The woodcutter's learning process is comprehensive and concerns not only his role as father but also his trade. His failure to protect his children is followed by his failure to find his way in the woods so that he has to rely on the help of a wise woman to 'get back on track'. This includes the fact that the wise woman introduces him, a man living off the woods, to treasures such as fruit and herbs and their healing functions. Another lesson in the father's re-education is the wise woman's own tale: she and her twin sister were also abandoned children, which caused her sister, consumed by hate, to become evil (the witch), while the wise woman herself accepted the situation and learned to use it for good ends. This story is an attempt to give the witch a socio- 
psychological explanation. However, the story is even more important for the cultural references which the twin sisters embody and contribute to the debate about communal values.

Witch and wise woman (both played by Anja Kling) are presented as cultural, moral and visual opposites. The witch personifies hate and revenge, the wise woman kindness and benevolence; the witch lives in a dark, factory-like house (which includes a laboratory) with a brightly coloured façade made out of sweets, the wise woman lives in a naturally grown tree-house; the witch needs the forest to seduce abandoned children into her kitchen and eats them (or turns them into tree stumps), the wise woman lives off the forest, collecting its plants and fruit and turning them into nourishment and remedies; the witch wears extravagant dress and makeup in bright colours, standing out from the muted colour palette of the surroundings, the wise woman's dress is colourful but relies on natural colours. 'Good' is a woman associated with nature, healing, truth, sustainability; 'Evil' is a woman associated with the artificial, falsehood, murder, and perverted consumerism.

In this context, the witch's link to an industrial setting is not accidental but indeed a reference to a politically unregulated capitalist economy, which is manifest also in the figure of a merchant who exchanges the woodcutter's wood for food. ${ }^{28}$ The

\footnotetext{
${ }^{28}$ The other obvious link is Roald Dahl's Charlie and the Chocolate Factory (1964), in which a high-tech sweet factory figures as a site of infinite pleasure and fantasy. Tim Burton's big-screen adaptation of the story from 2005 is of particular relevance here as Burton's Willy Wonka, the rather ambivalent founder of the factory and inventor of all the sweets, is given a socio-psychological backstory: a childhood trauma is presented as the cause of his investment in sweets as well as of what is marked as asocial behaviour. A further affinity with Burton might be seen in the twin
} 
merchant with his cart full of food is the representative of profit-making in the film: rich, unsympathetic, and hypocritical, he cites the 'law of the market' to justify his exploitation of the poor family:

Ja, ihr habt es gut! Die Bäume wachsen immer, ihr geht bloß in den Wald und holt sie raus. Aber was soll ich sagen? Letztes Jahr die Dürre! Die ganze Ernte ist komplett verdorrt. Alle haben die Preise angehoben. Das musste ich auch tun. Meint ihr, mir macht das Spaß?

His reasoning is exposed as false; he makes others starve while his children enjoy candy canes. The abundance of food and sweets in particular links the merchant and the witch closely, an affinity that is also highlighted by the colour scheme of the film as the merchant is the other character to wear 'artificial' colour and, like the witch, he prefers bright blue and turquoise.

The affinity between merchant and witch permits a reading of her as a metaphor of his exploitation: the rich merchant's refusal to give the poor family bread for the products of their work is metaphorically exposed as cannibalistic perversion through the witch, as literally 'feeding on others'. In this context it is hardly a coincidence that the witch keeps locusts in her laboratory, the economic meaning of which had been popularised in 2004 and 2005 by the then chairman of the Social Democrat Party Franz Müntefering and his opponents in the so-called 'Heuschreckendebatte'. Explicating freedom as part of responsibility for the community, Müntefering promised protection against the economic excesses of globalisation:

sisters who are abandoned and have to fend for themselves, one becoming a good, the other the evil witch taking revenge on the community (see Burton's adaptation of Sleepy Hollow from 1999). 
Zum Beispiel aber auch, wenn es darum geht, in der globalisierten Wirtschaft die Rechte derer zu schützen, die hilflos sind, wenn anonyme Aktionäre ihnen die Arbeitsplätze zerstören. Wir müssen denjenigen Unternehmern, die die Zukunftsfähigkeit ihrer Unternehmen und die Interessen ihrer Arbeitnehmer im Blick haben, helfen gegen die verantwortungslosen Heuschreckenschwärme, die im Vierteljahrestakt Erfolg messen, Substanz absaugen und Unternehmen kaputtgehen lassen, wenn sie sie abgefressen haben. $^{29}$

Müntefering's comparison, which has remained a catch-phrase until today, was criticised variously as undifferentiated, oversimplified and even denigratory. Similarly, the ARD adaptation offers an interpretation of the economy that relies on clear-cut moral opposites linked to fears of modernity, which indeed invoke romantic visions of the late $19^{\text {th }}$ century favouring idealistic idylls. In line with the idealistic tradition there is no material reward for Hänsel and Gretel. While the ZDF allowed the children to return home to their poor father loaded with the treasures of the witch (as in the Grimms' version), the ARD follows Humperdinck and replaces material compensation with family reunion and resurrection. ${ }^{30}$ After enhancing the tale with a

${ }^{29}$ Franz Müntefering, 'Freiheit und Verantwortung. Das neue Grundsatzprogramm der SPD', talk given on 22 November 2004 in Berlin; published in Programmhefte 1, January 2005, p. 18; <www.spd-werlte.de/pdf/programmheft1.pdf > [accessed 17 March 2015].

${ }^{30}$ This ending even resonates with Burton's Dahl adaptation in which Charlie at first refuses to inherit the chocolate empire as this would mean leaving his family behind; Charlie however values family over property even though this means living in poverty. 
socio-economic causal nexus, the question of how the family is going to survive remains untouched. The Presseheft suggests a moral lesson instead:

Vertraue nicht sofort dem äußeren Schein — mag er noch so süß und verlockend sein. Und: Wenn du einen Fehler machst, warte nicht ab, sondern versuche aktiv, dein Fehlverhalten zu korrigieren. ${ }^{31}$

The replacement of socio-political problems with morality reflects on the figure of the child which is idealised as emotional and moral authority within the family and wider community, but at the same time is obliterated as socio-economic reality. A similar process of obliteration is at work in Rotkäppchen.

\section{Rotkäppchen: The Family is the Smallest Cell of the State}

One feature that can be deduced even in passing from the above discussions becomes more visible in Rotkäppchen, namely that communal cohesion is also always based on heteronormativity.

Rotkäppchen opens with a juxtaposition of the sleeping inhabitants of a peaceful village embedded in a beautiful landscape and, in a series of point-of-view shots, a wolf drawing nearer the village and breaking into a chicken house. This threat from outside is complemented by a conflict within the village community at the hands of which Rotkäppchen and her mother suffer frequent taunting due to the mother's status as single and unmarried and Rotkäppchen's as illegitimate. The grandmother with her house in the woods highlights this all-female family as positioned at the margins, a place which turns out to be ambivalent, namely isolated as well as productive. As the family is not an integral part of the community, it suffers from seclusion but also has room for an unconventional and experimental life. The

\footnotetext{
${ }^{31}$ Martin Hofmann, Presseheft 2012, p. 13.
} 
grandmother's motto ‘Gewöhnlich sein kann jeder', which Rotkäppchen adopts, reflects the coincidence of creativity and isolation.

The community's rejection is represented directly by the village children, whose open bullying functions as mouthpiece for the adults' opinions, and indirectly by Frau Bürgermeister, the exponent of the ruling power. Thus the story of the girl, who is punished for breaking her promise to her mother by leaving the right path, becomes the story of a family marginalised by a community which cannot solve the conflict arising from its socio-economic order and moral conventions. The adaptation looks at a complex reality which results in a marked increase in characters with differing degrees of complicity in the conflict; indeed, Rotkäppchen herself can hardly claim the central role anymore. Beside the mother, a dressmaker who works hard to provide for her daughter, and the grandmother, an extravagant elderly lady who invents unusual machines, there is the huntsman, young and in love with the mother, Anton, a boy who likes Rotkäppchen and tries to help her, and Frau Bürgermeister, a comic character distinguished by pomposity, bad taste and malapropism which affects all the French words with which she tries to show off. Each of these characters has to learn a lesson in order to eventually solve the conflict, a massive educational programme realised in a number of sub- and parallel plots. The story of Anton, who functions as the male counterpart to Rotkäppchen, is of particular interest: Anton is bullied by the other children for being fearful; his repeated attempts to convince the village children first of the imminent danger and then of Rotkäppchen's rescue, and his brave challenge of the wolf in order to save lives almost recommend him as the main protagonist.

The conflict is solved in the end, though given the complexity of the problem the solution goes beyond the rescue of grandmother and Rotkäppchen and the death of 
the wolf; it now includes the mother's engagement to the huntsman and Rotkäppchen's new friendship with Anton who are both integrated into the group of village children. Revival and consolidation of the community is thus linked to the reinstatement of heterosexual couples across the generations. This solution undermines the all-female family retrospectively as incomplete, and explains its vulnerability with the lack of men.

Throughout the seasons there exists compulsory heterosexuality based on traditional gender roles. Rotkäppchen is fearless and self-confident, but her scope for action remains limited. While she keeps the wolf checked by intrepidity for a while, she can never defend herself successfully as for example the old DEFA Rotkäppchen (Götz Friedrich, 1961) did before she was outwitted by the cunning fox that helped a rather wretched wolf by putting on acts and setting traps. In the ARD adaptation Rotkäppchen is not overcome by such mutability of Evil, but by the lack of male figures that could protect her effectively. There is a high pressure to be 'paired', which leaves Rotkäppchen and her mother, like many other female characters of the seasons,${ }^{32}$ with the traditional role of the one in need of a hero. In times of rising numbers of divorces and single-parent households, ${ }^{33}$ not to mention the diversification

${ }^{32}$ In Frau Holle (Bodo Fürneisen, RBB 2008) both girls and the mother find partners in the end; in Die kluge Bauerntochter (Wolfgang Eißler, MDR 2009) both the Prince and his mother, the Queen, find partners, which is also the case in Der Froschkönig (Franziska Buch, SWR 2008), Das tapfere Schneiderlein (Christian Theede, NDR 2008), Tischlein deck dich, Rapunzel (Bodo Fürneisen, RBB 2009), and Der Meisterdieb.

${ }^{33}$ Statistisches Bundesamt, Alleinerziehende in Deutschland. Ergebnisse des Mikrozensus 2009, 
of partnerships,${ }^{34}$ the dream of the traditional, biological nuclear family with the protector-father and the woman-in-the-house is reinstalled in the most beautiful colours. Rotkäppchen and her grandmother completely misjudge the woods as a place of danger and battle, which only the huntsman and Anton are able to confront. In the last scene Rotkäppchen and her mother are shown as happily confined in the interior and village. It is noteworthy that the grandmother, the most adventurous and independent female character, is left out of the finale. The final integration of the women in the community removes the place at the margins and with it the unconventional creativity.

Fig.1 The DEFA Rotkäppchen defeating the wolf in a first battle in the woods and thus contending his territory. It is noteworthy that during this battle Rotkäppchen is always placed above the wolf. CDEFA-Stiftung/Helmut Bergmann

Fig. 2 From the beginning the wolf dominates Rotkäppchen in the ARD adaptation; particularly the first encounter presents Rotkäppchen with low and the wolf with high angle reverse shots.

Fig. 3 Anton's first encounter with the wolf is a reversal of the power hierarchy in that Anton looks down on the wolf. The translation of power relations into differences of

<https://www.destatis.de/DE/PresseService/Presse/Pressekonferenzen/2010/Alleinerzi ehende/pressebroschuere_Alleinerziehende2009.pdf?_blob=publicationFile> [accessed 30 January 2015].

${ }^{34}$ See for example the Act on Registered Life Partnerships from 2001 <http://www.rechtliches.de/info_LPartG.html> [accessed 18 February 2015]. 
height is also apparent in the relation between Rotkäppchen's mother and Frau Bürgermeister.

As with the family reunion in Hänsel and Gretel, the focus on heterosexuality in Rotkäppchen neglects other causes for the family's suffering. While the film initially makes an effort to present a complex picture of a community, socio-economic mechanisms of marginalisation and exclusion are overcome in the end not because the village undergoes democratisation or pluralisation, but because Rotkäppchen and her mother happily conform to the heterosexual pact after all.

The comprehensive reconciliation functions as an endorsement of the status quo and its socio-political hierarchy as illustrated by the character of the mayor's wife. Frau Bürgermeister occupies a sub-plot evolving around a festive dress, which Rotkäppchen's mother is to make. While the mother suggests a simple, yet elegant blue dress, Frau Bürgermeister insists on pompous golden attire in order to look Parisian, not rural and German. Indeed, her obsession with pomp and self-importance is the catalyst of the catastrophe. Pride and presumptuousness are undoubtedly criticised in the film. However, this does not cause a challenge to the socio-political hierarchy which Frau Bürgermeister represents. Instead, a public humiliation which reforms her as an individual, replaces any questioning and change of the order. Her malapropism is still ridiculous but the reformed Frau Bürgermeister proves a true representative of the people by wearing the dress designed by Rotkäppchen's mother after all.

Que souper! Das nenn' ich ein wahres Meisterwerk. ... Puffärmelchen sind ja so was von purée! 
The unchallenged position of Frau Bürgermeister is indicative of a more general treatment of power and hierarchy in the seasons.

\section{Long Live the Ruling Class!}

The DEFA adaptation of Das tapfere Schneiderlein from 1956 (Helmut Spieß) ends with the victory of the tailor who drives not only the malicious king and his advisors away but, unlike the Grimms' tailor, DEFA's also prefers the chambermaid to the proud princess. The triumph of the 'common man', who succeeds through courage and cunning, does not leave room for reconciliation with the ruling class. It would be wrong to claim that this is the case in each fairy tale adaptation produced by DEFA, however the downfall of the king and his court as well as a particular emphasis on the people's lives remained dominant throughout East German fairy tale production. ${ }^{35}$ Mary Fulbrook described the GDR dictatorship as, amongst other things, paternalistic, i.e. a state under a highly authoritarian party leadership that treated the people as minors in need of protection as much as control. ${ }^{36}$ In such a politically incapacitating context, fairy tale adaptations rehearsed the revolt from below against the authoritarian 'king father'. One can call this an ersatz for the real revolt, but what

\footnotetext{
${ }^{35}$ Other examples of a focus on the people and their open opposition to the rulers include DEFA big screen adaptations such as Das Feuerzeug (Siegfried Hartmann, 1953), Sechse kommen durch die Welt (Rainer Simon, 1972), Wer reißt denn gleich vorm Teufel aus (Egon Schlegel, 1977), and TV-adaptations such as Die zertanzten Schuhe (Ursula Schmenger, 1977) and Die Gänsehirtin am Brunnen (Ursula Schmenger, 1979).

${ }^{36}$ Mary Fulbrook, Anatomy of a Dictatorship: Inside the GDR 1949-1989 (Oxford: Oxford University Press, 1995), pp. 29-30.
} 
does one call it when the democratic and pluralistic, unified Germany produces fairy tales that engage in dreams of the king as the caring and benign ruler over his people?

The ARD adaptations abstain from developing the people's story and instead focus on the conditions of government. A first feature of this approach is the congenial image of the ruler given in a good number of the films. Thus Das tapfere Schneiderlein (Christian Theede, NDR 2008) presents a generous and friendly king who loves his daughter and good food, particularly plum jam like the tailor. The king's only fault is that he is too weak and therefore unable to oppose his powerhungry advisors. Such a shift in blame is not new and has an immediate precursor in the ZDF-commissioned adaptation from 1988 (Dusan Trancik), which focused on the ideological mechanisms of power preservation. This late 1980s film reflected the political situation at the demise of the Eastern Bloc by presenting the king as a prisoner of his own mythic legitimation and cut off from the realities of life. The postunification interpretation by the ARD does not offer such a politically critical metaphor but paints an ideal picture of 'good power' as kind, loving, and innocent. ${ }^{37}$ The 'good power' is fully realised by the next generation who defeat the bad advisors that threaten to abuse the rule of the old king. The three elements that symbolise the old king's benevolence are his deep concern for the kingdom's well-being, his true love for his child, and his closeness to the 'common people' indicated not only by his liking of plum jam but also of the palace cook; last but not least the good ruler is often inoffensively eccentric, a figure of mild comic effect.

The ruler as a benevolent figure also appears in Die Gänsemagd (Sibylle Tafel, HR 2009), Der gestiefelte Kater (Christian Theede, NDR 2009), Die kluge

\footnotetext{
${ }^{37}$ Indeed, a number of ARD kings have very little interest in power and this in particular seems to make them good kings.
} 
Bauerntochter (Wolfgang Eißler, MDR 2009), and Die Prinzessin auf der Erbse (Bodo Fürneisen, RBB 2010). The familiarity between ruler and people as the dominant characteristic of 'goodness' takes various forms such as friendship between prince and goose boy (Die Gänsemagd), the willingness of the king to embrace the miller's family as his own (Der gestiefelte Kater), the queen-mother's love for her advisor, a former miller (Die kluge Bauerntochter), the king's trust in his captain, a man who grew up in the alms-house orphanage, or the prince's secret training as a carpenter $^{38}$ (Die Prinzessin auf der Erbse). Familiarity, even intimacy with the 'common people' functions as a strategy of legitimation: social permeability is celebrated in these films as an advantage of the existing order and its justification at the same time, rendering any changes unnecessary.

Beside the figure of the benevolent ruler there is the figure of the incapable ruler who by ignorance, selfishness, greed or sorrow neglects his responsibilities and causes his people to suffer as in Dornröschen (Oliver Dieckmann, SWR 2009), Rumpelstilzchen (Ulrich König, WDR 2009), Des Kaisers neue Kleider (Hannu Salonen, WDR 2010), Der Meisterdieb or Die Sterntaler. The economic and social consequences of misgovernment such as poverty, depopulation, and economic and cultural decline are described in considerable detail, which gives the tales an explicitly political and economic grounding. However, despite the rulers' failure the existing order is always presented as capable of solving the problems so that opposition and rebellion from the people are completely absent from the adaptations. The restoration of order arises from the replacement of the bad representative of 'good power' with the good representative — Die Sterntaler and Rumpelstilzchen or the moral reformation of the bad representative - Dornröschen, Der Meisterdieb

\footnotetext{
${ }^{38}$ This is reminiscent Albert Lortzing Zar und Zimmermann (1837).
} 
and Des Kaisers neue Kleider. The resolution of conflict and the harmony always achieved in the end are thus never based on change but rest on the paternalistic order in which the ruler at the top remains the warrant of the common good.

Her village's extreme poverty forces Mina in Die Sterntaler on her way to the king. She wants to persuade him to free her parents and all the other weavers in her village whom the king is keeping imprisoned until they have worked off their alleged tax debts. On her journey, Mina witnesses the misery of individuals, families and communities whom she is able to help due to her extraordinary courage, honesty, and unselfishness. The Grimms' tale of unshakeable trust in God is turned into a tale of unshakeable trust in humanity represented by an angel-like girl. The innocence of the child functions as a great healing force until she faces the king, the representative of the order which causes most of the suffering and destruction described in the film. However, the resolution Mina achieves - due to the miracle of the Sterntaler she can buy her village community out — remains unsatisfactory in the context of the film as it does not answer the magnitude of the social and economic problems outlined above. It therefore needs a political supplement, which is provided by the figure of the queen. Unlike the king, the queen responds to Mina and her tale, which distinguishes her as a ruler sensitive to the needs of the people. Furthermore, the queen's response is not just emotional but political as she immediately understands the implications of common poverty for the state. The king's tax policy aims at proportionally increasing the debts for the weavers whereas the queen pursues sustainability:

Und wenn ihr sie frei lasst, dann könnten sie in ihrem Dorf eine neue Generation Weber ausbilden und damit auf lange Frist deutlich mehr Steuern zahlen. 
The king is punished and removed, and the audience can assume that the sensible queen will take over. What the film thus circumvents is the conflict between people and ruler that is brewing not only in the narrative but the images as well, particularly those of the imprisoned weavers: the scene showing the weavers living and weaving in the dark cellars of the castle is reminiscent of a $19^{\text {th }}$ century workshop and loaded with associations of a faceless and exploited working class. It is difficult not to think of lines such as 'Wacht auf, Verdammte dieser Erde'39 or 'Deutschland, wir weben dein Leichentuch' ${ }^{40}$ And yet, the revolt encapsulated in the scene is not developed but countered, indeed undermined by the figure of Mina. For the first time the girl's angelic appearance, particularly her long hair that in true fairy tale fashion shines like spun gold, finds a stark and unresolvable contrast in the black of the cellar; her open look — close-up frontal shots of her face - is countered by the hushed and hidden looks of the weavers and their dirty and shadowy faces. There is no visual affinity between Mina and the 'damned of this earth'. While Mina is seen throughout the film re-linking people and places, the underworld in which her parents and village vegetate remains cut-off and cannot be connected to any other place. Between the cellar and the rest of the mise-en-scene there is no exchange or correspondence. Instead, analogies to Mina, and particularly her hair, all come from above either literally in the case of the twinkling stars and the shower of gold or metaphorically in the figure of

\footnotetext{
${ }^{39}$ Eugene Pottier, 'Die Internationale', <https://www.marxists.org/history/ussr/sounds/lyrics/international.htm> [accessed 17
} March 2015].

${ }^{40}$ Heinrich Heine, 'Die Schlesischen Weber', in Nachlese, Digitale Bibliothek, vol. 7 (Berlin: Directmedia, 1998), p. 343-44. 
the queen, who is the other character in the film with hair as golden and lustrous as Mina's.

\section{Conclusion}

Just as the Grimms' study and editing of fairy tales was founded on imagining

Germany, so the revisiting of the tales has often been part of national identity politics, and the latest ARD adaptations confirm such an agenda. However, Sechs auf einen Streich is not a nationalist project; the aim is not to define a national character or to prove its superiority. Rather, the purpose of the series seems to be to re-create the national past as an ideal of peacefulness and harmony still yielding its wisdom to the present. 'What typifies heritage filmmaking is the production of usable and consumable pasts, of history as a site of comfort and orientation. ${ }^{41}$ Thus the films offer notions of German Heimat based on a past in which all conflict was solved without upheaval and the following communal reconciliation was comprehensive. This notion of the past contains the promise of a national history without unresolved conflict or desideratum.

Children and adolescents are offered as main protagonists with whom the audience is to identify emotionally most of all on moral grounds: the young denote not so much innocence but moral superiority over the adult world and, as facilitators of social harmony within the films they reinstate morals as the most important social driving force over economic or political interests though these are always a prominent part of the films' exposés. Furthermore, the morals offered as valid guidance are based on ideals of wholeness and completeness which favour conservative concepts such as that of heteronormativity, the biological nuclear ('organic') family, or the

\footnotetext{
${ }^{41}$ Lutz Koepnick, 'Reframing the Past', p. 51.
} 
closed community. Within this framework, the young re-generate the traditional social unit.

The ideals propagated by the films obliterate conflict and devalue concepts beyond the traditional. Therefore, the next generation's empowerment rests entirely on its function within the community, to which it remains completely bound. There is no place beyond the family, village or region. Some of the films end with the adolescent's resolution to travel the world - Der Froschkönig (Franziska Buch, SWR 2008), Sechse kommen durch die ganze Welt (Uwe Janson, RBB 2014), ${ }^{42}$ — but the geographical, ethnic, cultural, religious 'other' is never part of the plot nor has it entered the Heimat-setting. Similar to the obliteration of driving forces, this restrictive notion of Heimat limits the young generation to a fantasy of homogeneity. The result of such a contained image of the German past is the exclusion of any other from the thirty-four films. Indeed, the appeal of Heimat seems to lie in its 'purity' as a result of seclusion and separation from the rest of the world - a state that is neither representative of present day Germany nor of the historical periods alluded to in the individual adaptations.

Within the context of heritage filmmaking, the fairy tale project can thus be understood as part of the bigger phenomenon described by various critics — with regard to post-unification films about the Nazi past but also the East German dictatorship — as a 'revisionist project' driven by 'what appears to be the widespread

\footnotetext{
${ }^{42}$ Die kleine Meerjungfrau (Irina Popow, MDR 2013) is an exception as she herself is an other; she is also the only main character who does not form a heterosexual couple at the end of the film.
} 
desire for a less problematic relationship to German history' ${ }^{43}$ With regard to the films' target audience, children and young adolescents, the question arises as to whether their traditional, indeed conservative outlook does provide a compass for the generation coming of age after the end of the Cold War. ${ }^{44}$

${ }^{43}$ Sabine Hake, Screen Nazis: Cinema, History, and Democracy (Wisconsin: The University of Wisconsin Press, 2012), p. 237.

${ }^{44}$ The revival of the fairy tale within the heritage mode and its nostalgic longings is, not surprisingly, successful not only in Germany but also abroad where the films serve as a German trademark. The fairy tales received the following awards: Die Sterntaler, Best of Fest Award at the Chicago International Children's Film Festival 2011, Hänsel und Gretel, Certificate of Merit-Award in the category Children's Programme at the $49^{\text {th }}$ International Film Festival in Chicago 2013, Das Mädchen mit den Schwefelhölzern (Uwe Janson, RBB \& SR 2013) Silver Television Award at the Chicago International Film Festival category Children's Film. The series are also international best-sellers: 'Aus der Sicht des Weltvertriebs kann man die Verwertung der ARD-Märchenfilme als recht erfolgreich bezeichnen. Im folgenden [sic.] finden Sie eine Liste [der Länder, UW], in die [die] Märchenfilme lizensiert werden konnten, wobei nicht alle Filme in dieselben Territorien verkauft wurden: Frankreich, Afrika (französisch-sprachig), Schweiz (französisch-sprachig), Belgien (französischsprachig), Italien, Monaco, Niederlande, Belgien (flämisch-sprachig), Polen, Tschechische Republik, Slowakei, Ungarn, Estland, Lettland, Litauen, Slowenien, Montenegro, Serbien, Bosnien-Herzegovina, Mazedonien, Albanien, Russland, Weissrussland, Ukraine, Kasachstan, Moldawien, Armenien, Aserbeidschan, Georgien, Tadschikistan, Turkmenistan, Usbekistan, Türkei, Zypern, Israel, USA, 


\section{Notes on Contributor}

Ute Wölfel is lecturer in German at the University of Reading where she teaches and researches German film and literature. She has published widely on German films dealing with the Nazi past as well as on the literature and culture of the GDR.

Kanada (französisch-sprachig, englisch-sprachig), Australien, Brasilien, Japan, Taiwan.’ Email from Valentina Grazzi, Pressestelle of RBB (22 May 2014). 